\title{
Quality of pomegranate peel cultivar Valenciana as determined by different drying methods
}

\author{
Gabriel Danilo Shimizu ${ }^{1}$, Jean Carlo Baudraz de Paula ${ }^{2}$, \\ Carmen Silvia Vieira Janeiro Neves ${ }^{3}$, Camilla de Andrade Pacheco ${ }^{4}$
}

\begin{abstract}
The pomegranate fruit exhibits medicinal properties due to the nutraceutical characteristics, especially of its peel. The objective of this study was to analyze the influence of different drying methods on the physicochemical and biochemical characteristics of the pomegranate peel. The experiment was conducted in a completely randomized design in subdivided plots: 4 (full sun [SUN], drying chamber [DC] at $60 \pm 2{ }^{\circ} \mathrm{C}$, cold chamber at $10^{\circ} \mathrm{C}$ and $60 \%$ relative humidity $(\mathrm{RH})$ $[\mathrm{CC}]$, solar dryer $[\mathrm{SD}]) \times 2$ (presence or absence of $1 \%$ ascorbic acid [AA]). The analyzed variables were mass loss, index of drying heterogeneity (IHD), Hue internal (LI, CI, HI) and external (LE, CE, HE) angles, as well as Chroma, of the peel, and finally, total phenolic compound (TCFT) and flavonoid (TFLA) content. DC treatment led to the shortest drying time, followed by SUN and SD treatments. A reduction in IHD was observed with respect to time, which was more pronounced in DC treatment. CC treatment produced a more positive response both for LI and LE. TCFT and TFLA content produced from DC treatment presented an interaction effect, which was reduced by the application of AA. On the other hand, dehydration without the application of AA in the drying chamber or in full sun resulted in the best responses in TCFT and TFLA content.
\end{abstract}

Index terms: storage, postharvest, Punica granatum $\mathrm{L}$.

\section{Qualidade da casca de romã, cultivar Valenciana, em função do método de secagem}

Corresponding author: shimizu@uel.br

Received: July 26, 2019 Accepted: December 02, 2019

Copyright: All the contents of this journal, except where otherwise noted, is licensed under a Creative Commons Attribution License.

\section{(cc) $\mathbf{E Y}$}

\begin{abstract}
Resumo-A romã é uma fruta considerada medicinal devido às características nutracêuticas, em especial de sua casca. Assim, objetivou-se analisar a influência de diferentes métodos de secagem nas características físico-químicas e bioquímicas da casca de romã. O experimento foi conduzido em delineamento inteiramente casualizado, em esquema de parcelas subdivididas: 4 (pleno sol [SOL]; estufa $60 \pm 2^{\circ} \mathrm{C}$ [E60]; câmara fria $10^{\circ} \mathrm{C}$ a $60 \% \mathrm{UR}$ [CF]; secadora solar [SS]) x 2 (presença ou ausência de ácido ascórbico [AA] a 1\%). As variáveis analisadas foram: perda de massa; índice de heterogeneidade de secagem (IHS); luminosidade, Chroma, ângulo Hue interno (LI, CI, HI) e externo (LE, CE, HE) da casca; compostos fenólicos totais (TCFT) e flavonoides (TFLA). O tratamento E60 apresentou menor tempo para secagem, seguido dos tratamentos SOL e SS. O IHS apresentou redução em função do tempo, sendo mais acentuada no tratamento E60. Para o LI, a CF apresentou melhor resposta, sendo o mesmo observado para LE. O TCFT e TFLA apresentaram efeito de interação, em que a aplicação do AA na secagem em estufa resultou em uma redução acentuada. Por outro lado, a secagem sem a aplicação de AA, na estufa ou a pleno sol, resultou nas melhores respostas no TCFT e TFLA.
\end{abstract}

Termos para indexação: armazenamento, pós-colheita, Punica granatum L.

\footnotetext{
${ }^{1}$ Mastering in agronomy, State University of Londrina, State University of Londrina, Londrina, Paraná, Brazil, E-mail: shimizu@uel.br (ORCID 0000-0001-8524-508X)

${ }^{2}$ Doctoral student in agronomy, State University of Londrina, Londrina, Paraná, Brazil, E-mail: jc_baudraz@live.com (ORCID 0000-0002-3695-3386) ${ }^{3}$ Teacher, State University of Londrina, Londrina, Paraná, Brazil, E-mail: csvjneve@uel.br (ORCID 0000-0001-9000-167X)

${ }^{4}$ TTeacher, State University of Londrina, Londrina, Paraná, Brazil, E-mail: camillaap@uel.br(ORCID 0000-0001-8067-3181)
} 


\section{Introduction}

Pomegranate (Punica spp.) is one of the oldest known edible fruits in the world, and is currently produced on a major commercial scale by the world's largest fruit producers including India, China, and Iran (HOLLAND and BAR-YA'AKOV, 2008). Brazil has gained prominence as a pomegranate-producing country in the last 7 years, due to a sharp increase in the volume of marketed pomegranate by the CEAGESP (Centro de Entrepostos e Armazéns Gerais de São Paulo), thereby creating competition with the fruits imported from Spain, the United States of America, and Uruguay, and resulting in an expansion of the cultivated fruit area in the country (WATANABE and OLIVEIRA, 2014).

Pomegranate can be grown in gardens as an ornamental plant, and is used in the chemical industry in the manufacture of paints. It is primarily used in natura since the aril, peel and seed of the fruit have nutraceutical characteristics with health benefits to those who consume them (OMAIAA, 2011).

The peel is the part of the fruit with the highest levels of minerals (potassium, calcium, phosphorus, magnesium and sodium), complex polysaccharides, and bioactive compounds (phenols, flavonoids, punicalagins and their isomers, galactic acid, ellagic acid, and glycosides of ellagic acid) (JALAL et al., 2018; SAAD et al., 2012; SALGADO et al., 2012; QU et al., 2012; CRISTOFORI et al., 2011; SEERAM et al., 2006). Therefore, in addition to the use of healthy fruits, the production of a high quality peel is dependent on an optimized drying process, in order to reduce deterioration by moisture and favor post-harvest shelf life (SANTOS, 2010).

The available drying methods (e.g., air-circulating drying chamber, microwave-assisted hot air, refractory window, and gas dryers) generate high pollution rates and require a high initial investment which puts the small producer at a disadvantage (SANTOS et al., 2017; TONTUL and TOPUZ, 2017; MACHADO et al., 2012). However, there are alternative methods, such as drying in the sun and using a solar dryer, which generate clean energy through renewable sources, and therefore do not impact the environment as they do not emit pollutants (MACHADO et al., 2012).

Despite the wide range of available drying methods aimed at the dehydration of products, little is known about the effects of high temperatures and ascorbic acid on the final quality of dehydrated pomegranate peel. This highlights the practical and scientific importance of this study, since high temperatures can result in the loss of bioactive compounds in fruits (TONTUL and TOPUZ, 2017), and also because the use of ascorbic acid can reduce quinones to phenols, thus inhibiting the darkening of the peel (COSTA, 2010). The present study aimed to analyze the influence of ascorbic acid on the inhibition of darkening in dehydrated pomegranate peel, as well as to evaluate the physicochemical and biochemical characteristics of the peel using different drying methods.

\section{Materials and methods}

The pomegranate fruits (Punica granatum L.) used in this study belonged to the variety "Valenciana", and were harvested in January 2019 from a commercial orchard in the municipality of Assaí, State of Paraná $\left(23^{\circ} 22^{\prime} 30.2^{\prime \prime} \mathrm{S} 50^{\circ} 52^{\prime} 36.1^{\prime \prime} \mathrm{W}\right)$. The fruits were transported to the soil laboratory of the State University of Londrina (UEL), where they were washed under running tap water and surface sterilized using a $2 \%$ sodium dichloroisocyanurate solution for $10 \mathrm{~min}$.

Using knives, fruits were cut into six equal parts, each approximately $10 \mathrm{~cm}$ in length. The peel was manually separated from the pulp and washed first in running tap water, followed by deionized water, to remove all remaining pulp residues. Finally, the pomegranate peels were dehydrated using different drying methods.

The experiment was conducted in a completely randomized design, using a subdivided plot scheme. The drying methods employed in the plots were as follows: full sun (SUN), drying chamber at $60 \pm 2^{\circ} \mathrm{C}$ (DC), cold chamber at $10 \pm 2^{\circ} \mathrm{C}$ and $60 \pm 5 \% \mathrm{RH}$ (CC), and solar dryer adapted from the method described by Cornejo et al. (1991) (SD; Figure 1).

Peels in the subplots were treated with either $0 \%$ or $1 \%$ ascorbic acid. The temperature and relative humidity of the air in the solar dryer were recorded using a datalogger (Model: HT-500, Instrutherm) and evaluated every one minute (Figure 2A). Data collected from the full sun drying method are shown in Figure 2B. 

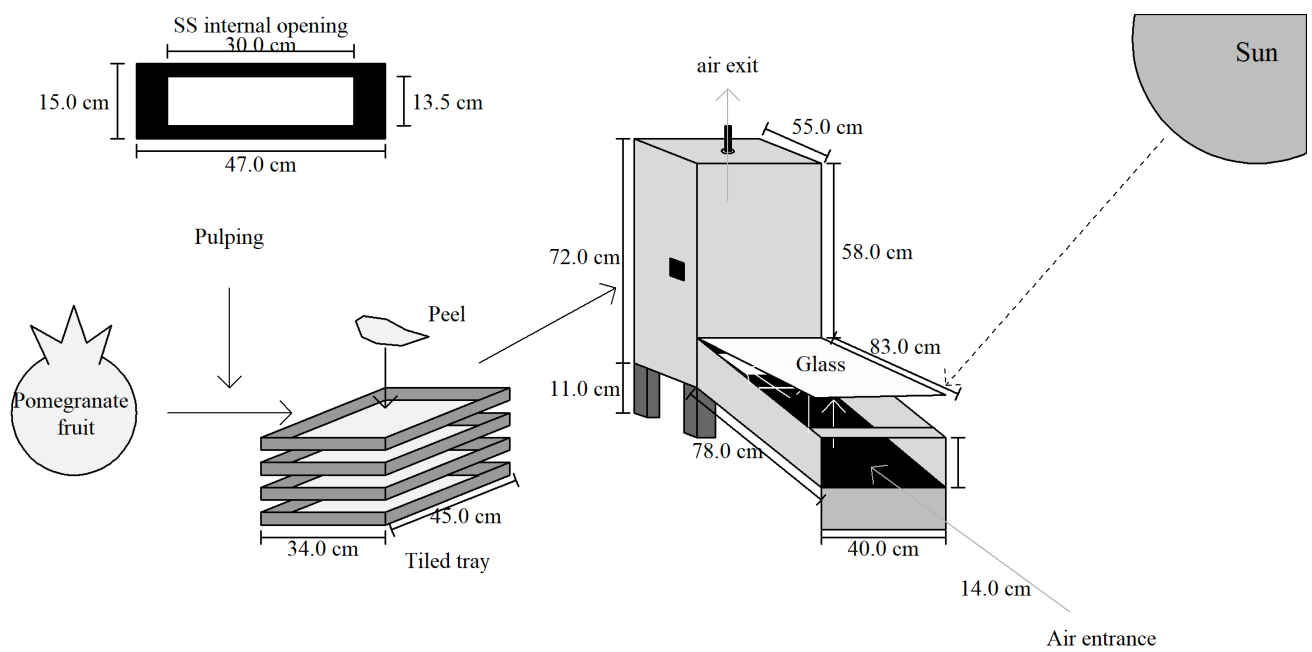

Figure 1. Diagram of the dimensions of the solar dryer and its components, adapted from the model of Cornejo et al. (1991)(Londrina-PR, 2019-Source: the author).

(A)

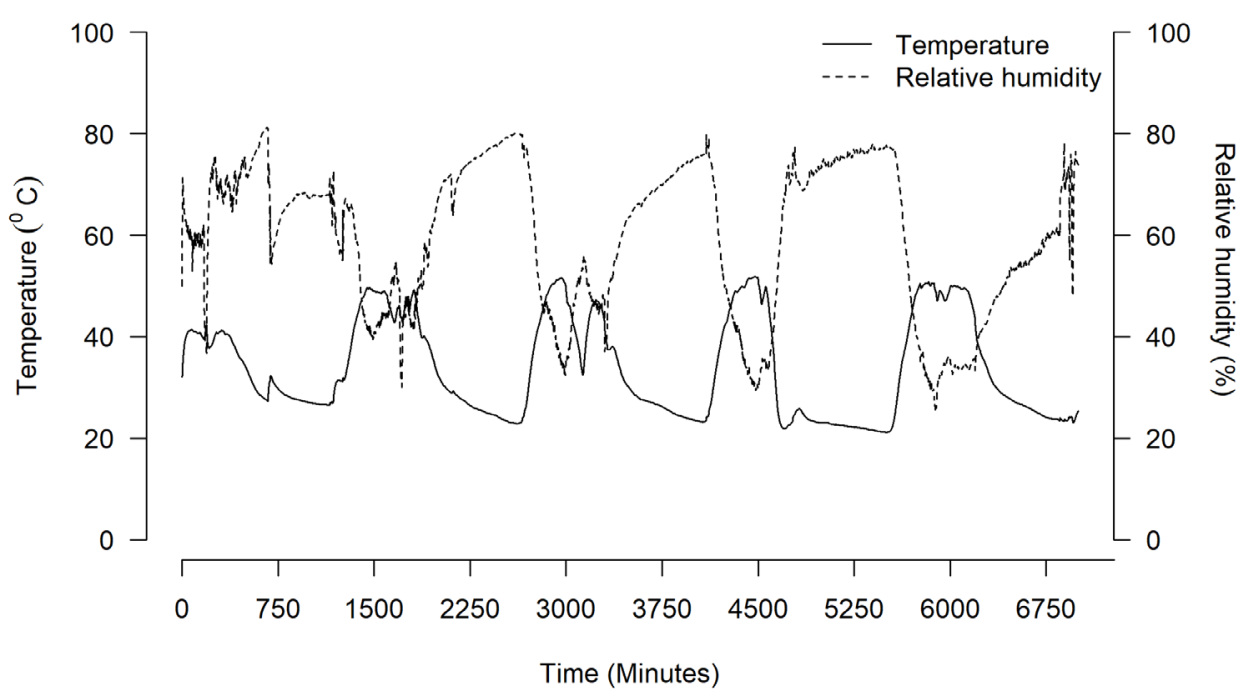

(B)

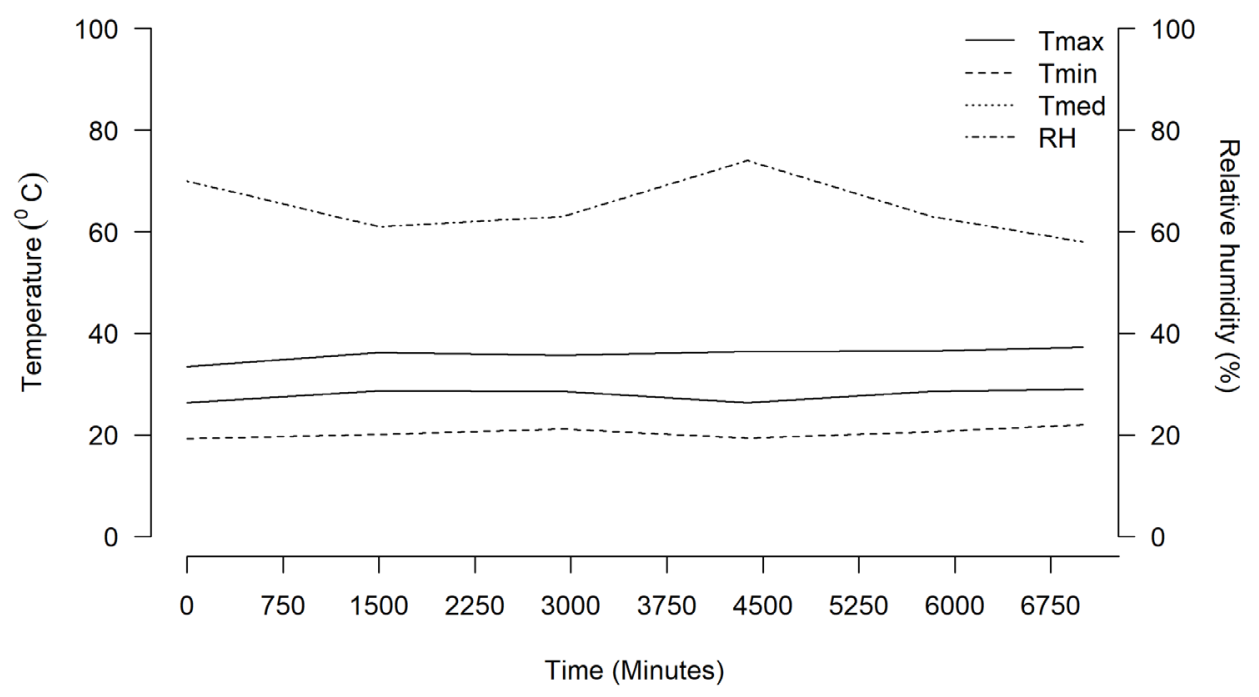

Figure 2.Temperature and relative humidity of the solar dryer (A) and ambient (B) from January $28^{\text {th }}$ to February $4^{\text {th }}$, 2019(Londrina-PR, 2019). 


\section{Physicochemical analysis of fruits}

Several physicochemical analyses were performed in 24 fruits. Titratable acidity (TA) was obtained by titration with a standardized solution of $0.1 \mathrm{~N} \mathrm{NaOH}$ until a $\mathrm{pH} 8.2$ was reached in the tested extract $(10 \mathrm{ml}$ of juice added to $40 \mathrm{ml}$ of distilled water), according to the described by AOAC method 942.15 (Association of Official Analytical Chemists, 1997). The results were expressed in $\mathrm{g}$ of organic acid (citric acid equivalent) per $100 \mathrm{ml}$ of extract. Total soluble solids (TSS) were determined by direct reading using a digital, hand-held refractometer (Model N1, Atago; Brix scale range 0.0 $-32.0^{\circ}$ ), and results were expressed in ${ }^{\circ}$ Brix. The ratio between total soluble solids and titratable acidity (Ratio), which indicates the maturation stage of pomegranate, was determined. Peel coloration was obtained by reading at 4 equidistant points in the equatorial region of the sample using a colorimeter (Model CR-300, Minolta), and by determining the $\mathrm{L}^{*}$ (indicating luminosity), $\mathrm{a}^{*}$ (indicating color variation from green to red) and $b^{*}$ (indicating color variation from blue to yellow) values (PAPADAKIS et al., 2000). Using $\mathrm{a}^{*}$ and $\mathrm{b}^{*}$ values, the Hue angle ( ${ }^{\circ} \mathrm{h}$ $\left.=\tan ^{-1}\left(b^{*} / a^{*}\right)\right)$, which defined color tint, and Chroma $\left(\left(C^{*}=\sqrt{\left.\left(a^{*}\right)^{2}+\left(b^{*}\right)^{2}\right)}\right.\right.$ which defined color intensity (MCGUIRE, 1992), were obtained. Longitudinal and transverse diameters of the fruit $(\mathrm{cm})$ were measured using a digital caliper (MTX $®)$. Fresh fruit mass (FFM), fresh peel mass (FPM), and fresh aril mass (FAM) were obtained using an electronic scale (with an accuracy of $0.01 \mathrm{~g}$ ), and the results presented in $\mathrm{g}$. The percentage of peel (PC) was also determined, where PC $=$ FPM/ FFM x 100 .

\section{Drying analysis}

During the drying process, fresh peel mass evaluations were performed in order to obtain mass loss, determined by calculating the difference between the initial fruit mass and values obtained at each stage of the analysis, using an electronic precision balance. The results were expressed as a percentage (\%). For each treatment, 8 repetitions were used, each with four replicates.

The index of heterogeneity drying (IHD) was obtained based on mass loss in each repetition, in function on the variability of the replicas, thus obtaining the average values of mass loss and the respective standard deviations at each repetition. The coefficient of variation was used to compare the uniformity of the drying process between treatments. The value that assumes each repetition is given by the formula:

$$
\mathrm{IHD}=\frac{\sum \sqrt{\frac{\left(\mathrm{X}_{1}-\overline{\mathrm{X}}\right)^{2}+\left(\mathrm{X}_{2}-\overline{\mathrm{X}}\right)^{2}+\left(\mathrm{X}_{3}-\overline{\mathrm{X}}\right)^{2}+\left(\mathrm{X}_{4}-\overline{\mathrm{X}}\right)^{2}}{\mathrm{n}-1}}}{\overline{\mathrm{X}}} \times 100
$$

where $\mathrm{X} 1, \mathrm{X} 2, \mathrm{X} 3$, and $\mathrm{X} 4$ are the values of mass loss in each experimental unit, $n$ is the number of experimental units, $\overline{\mathrm{X}}$ represents the mean repetition, and IHD is the index of heterogeneity drying.

At the end of the peel drying process, two measurements were performed on the inside of the peel (SILVA et al., 2014), and one on the outside, using a colorimeter (Model CR-300, Minolta). Four repetitions, each with four replicates, were carried out. Parameter $\mathrm{L}^{*}$ indicated the brightness factor; its value was a useful indicator of darkening, resulting from oxidative darkening reactions or increased pigment concentration (ROCHA and MORAIS, 2003).

\section{Analysis of total phenolic compounds and flavonoids}

An aqueous extract was prepared by adding $25 \mathrm{ml}$ of boiling water $\left(105^{\circ} \mathrm{C}\right)$ to $1.0 \mathrm{~g}$ of ground pomegranate peel, and the temperature monitored using a thermometer (Model ET 1415, Ecotools). After 35 minutes, the extract was stirred, filtered and refrigerated at $2-8^{\circ} \mathrm{C}$ in the dark, until required for further analysis, according to the method described by Cazarin et al. (2014).

The total phenolic compound content (FTCT) was determined according to the Folin Ciocalteau spectrophotometric method (SINGLETON and ROSSI JÚNIOR, 1965) using a gallic acid pattern, and the results expressed as the equivalent weight $(\mathrm{mg})$ of gallic acid (GAE) in $100 \mathrm{mg}$ of extract. The readings were performed using a spectrophotometer (Model AJX-1600, Micronal) at $765 \mathrm{~nm}$, and analyzed in duplicates.

For the quantification of total flavonoid (TFLA) content, $1.0 \mathrm{ml}$ of $5.0 \%(\mathrm{w} / \mathrm{v})$ aluminum chloride and $2.0 \mathrm{ml}$ of methanol were added to $1.0 \mathrm{ml}$ of aqueous extract, and incubated for $30 \mathrm{~min}$ in the dark. Samples were subsequently analyzed using a spectrophotometer (Model AJX-1600, Micronal) at $425 \mathrm{~nm}$ (WOISKY and SALATINO, 1998). Quercetin was used as the standard at concentrations of 50.0-500.0 mg L-1, and the results were expressed as the equivalent weight ( $\mathrm{mg}$ ) of quercetin (QE) per $100 \mathrm{mg}$ of extract.

\section{Statistical analysis}

Results obtained from physicochemical analyses were examined using descriptive methods (i.e. sample mean and standard deviations). Total phenolic compound, flavonoid and staining contents were submitted to variance analysis and the means compared using the Tukey's test $(p \leq 0.05)$. The assumptions of normality, homogeneity of variances and independence of errors were determined using the Shapiro-Wilk, Bartlett and Durbin-Watson tests $(p \geq 0.05)$, respectively. In cases where one of the assumptions was corrupted, the data were transformed 
according to the model proposed by Box and Cox (1964).

Mass loss and index of heterogeneity drying were analyzed by linear and nonlinear regressions $\left(Y=\frac{a \times x}{b+x} ; Y=a \times x^{b}\right)$.The relationship between variables analyzed at the time of drying was investigated using multiple linear regression analysis, with the index of heterogeneity considered as a response, while mass loss and time were regarded as explanatory variables. For the regression models, the test for the variance inflation factor (multicollinearity), partial F test, lack of adjustment, and Akaike and Bayesian inference criteria were analyzed, as well as the coefficient of determination and significance of the coefficients. The results were processed using the software R (R CORE TEAM, 2019).

\section{Results and discussion}

\section{Physicochemical Analysis}

The pomegranate fruits analyzed in the present study presented a total soluble solids content of 15.71

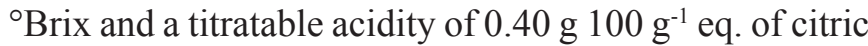
acid, with an average ratio of 37.52 (Table 1), considered high for the standards of main commercial varieties (TEHRANIFAR et al., 2010). However, these fruits were harvested in January, following a period of higher pomegranate supply and price on the market (SUZUKI, 2016), and met the quality attributes proposed by UNECE (United Nations Economic Commission for Europe, 2013) (Table 1), with the potential for marketing in the form of a by-product, i.e., dehydrated pomegranate peel. This provides an option of extra income for the producer, at a time when the fruit is devalued in the fresh fruit market, thereby generating fruit demand for industrial processing.

Table 1 - Physicochemical analysis of pomegranate fruits, variety 'Valenciana'(Londrina-PR, 2019).

\begin{tabular}{cc}
\hline Parameters & Values \\
\hline Fresh fruit mass $(\mathrm{g})$ & $304.4 \pm 27.8$ \\
Fresh aril mass $(\mathrm{g})$ & $184.6 \pm 22.0$ \\
Fresh peel mass $(\mathrm{g})$ & $119.9 \pm 28.7$ \\
Peel percentage (\%) & $37.5 \pm 10.6$ \\
Longitudinal diameter $(\mathrm{cm})$ & $8.3 \pm 0.3$ \\
Transversal diameter $(\mathrm{cm})$ & $8.0 \pm 0.4$ \\
Luminosity & $54.5 \pm 3.6$ \\
Chroma & $37.0 \pm 2.1$ \\
Hue angle & $60.2 \pm 8.0$ \\
Soluble solids $\left({ }^{\circ} \mathrm{Brix}\right)$ & $15.7 \pm 0.6$ \\
Titratable acidity $\left(\mathrm{g} 100 \mathrm{~mL}^{-1}\right)$ & $0.4 \pm 0.1$ \\
Ratio & $37.5 \pm 3.8$ \\
\hline
\end{tabular}

Average of 24 pomegranate fruits.

Analysis of the physical parameters of the fruits (Table 1) produced mean values of $304.38,184.61$, and $119.93 \mathrm{~g}$ for fresh fruit mass, fresh aril mass, and fresh peel mass, respectively. The percentage of peel was $37.50 \%$, indicating a significant volume of peel in relation to the total mass of fruits, which would generate a high yield for the pomegranate peel processing industries, thus corroborating the results found by Tehranifar et al. (2010) and Sarkhosh et al. (2009). Longitudinal and transverse diameters presented averages of 8.30 and 7.99 $\mathrm{cm}$, respectively. The fruits have been classified according to the standard established by UNECE, i.e. by diameter $(2 / \mathrm{B} ; 71-80 \mathrm{~mm})$ and mass $(3 / \mathrm{C}$; fresh mass from 301 to $400 \mathrm{~g}$ ), thus confirming the variety "Valenciana" to be medium-sized fruits and meeting the preferred standards of the organ as established by the consumer.
The fruits analyzed for peel color parameters displayed a Hue angle, luminosity and Chroma of 60.21, 54.53 and 36.99 , respectively (Table 1 ). These values indicated that the studied variety was undesirable for commercialization in the fresh fruit market, as it contained a predominance of the yellow color, and would not be favored by the consumer whose preference was for fruits with purple peel at a Hue of 32.00 (MASHAVHATHAKHA et al., 2014). However, "Valenciana" pomegranates offered other attributes such as percentage of peel, low acidity, and high soluble solids content, that would be more important to the industrial market (their target audience), beyond the external coloration of the fruit (MAYUONIKIRSHINBAUM;PORAT, 2014). 


\section{Drying analysis}

The loss of mass in the pomegranate peel displayed quadratic adjustment for SUN (With: $4782 \mathrm{~min}$ and response of 70.95\%; Without: 4899 minutes and 70.01\% response) and SD (With: $6886 \mathrm{~min}$ and response of 63.66\%; Without: 6403 minutes and $61.20 \%$ response) treatments, with or without the application of ascorbic acid (Figure 3). While CC treatment presented a simple linear adjustment, it did not display stability in the peel mass. DC treatment produced the best response in terms of time and stability after $1500 \mathrm{~min}$ following the start of the trial. Finally, the application of ascorbic acid resulted in a lower reduction in mass loss (Figure 3A), since this treatment introduced an increase in moisture when the peels were dipped in the solution and immediately subjected to the different drying methods.

(A)

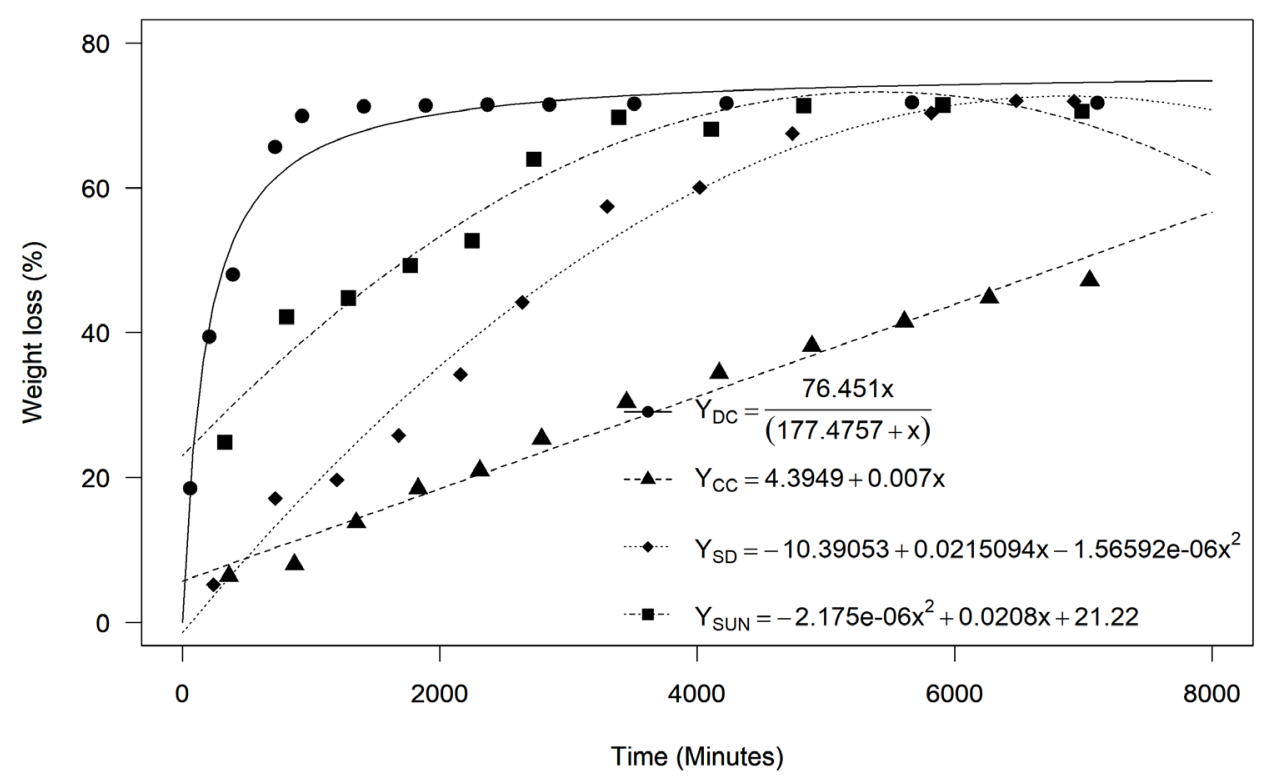

(B)

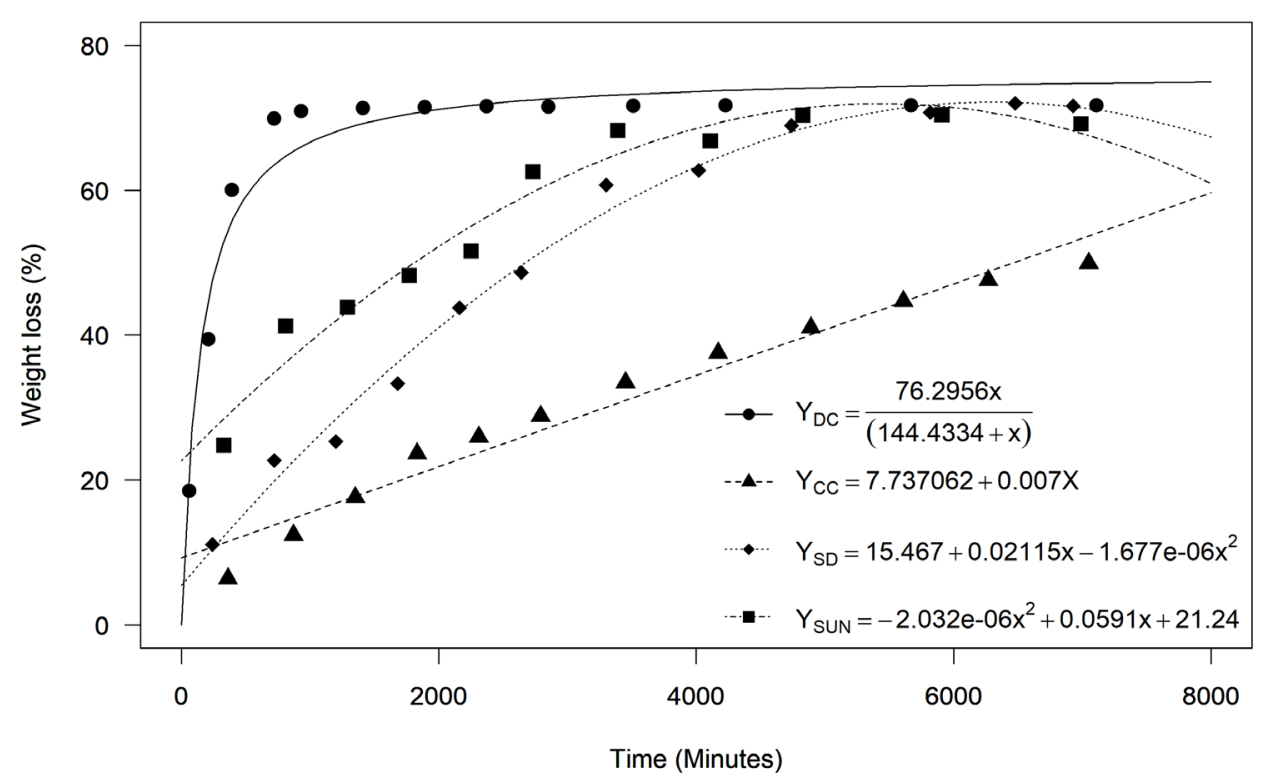

Figure 3. Mass loss in pomegranate peel subjected to 4 drying methods (Full sun (SUN), drying chamber at $60 \pm 2$ ${ }^{\circ} \mathrm{C}$ (DC), cold chamber at $10 \pm 2{ }^{\circ} \mathrm{C}$ and $60 \pm 5 \% \mathrm{RH}$ (CC) and solar dryer adapted from Cornejo et al. (1991) (SD)) with (A) and without (B) the application of 1\% ascorbic acid (Londrina-PR, 2019). 
The index of heterogeneity drying (IHD) of pomegranate peels for all treatments, including the application of ascorbic acid, showed a gradual reduction in variability with respect to time, being more pronounced in DC and less pronounced in CC (Figure 4). This was explained by the drying time, since both were correlated.
The relationship among IHD, time variables, and mass loss was explained using the multiple linear regression model, where all treatment conditions, as well as all observations, were analyzed. Following the start of the experiment, with the increase in time, a decrease in the mass of the peel was detected, which contributed to decreased drying heterogeneity (Figure 5E).

(A)

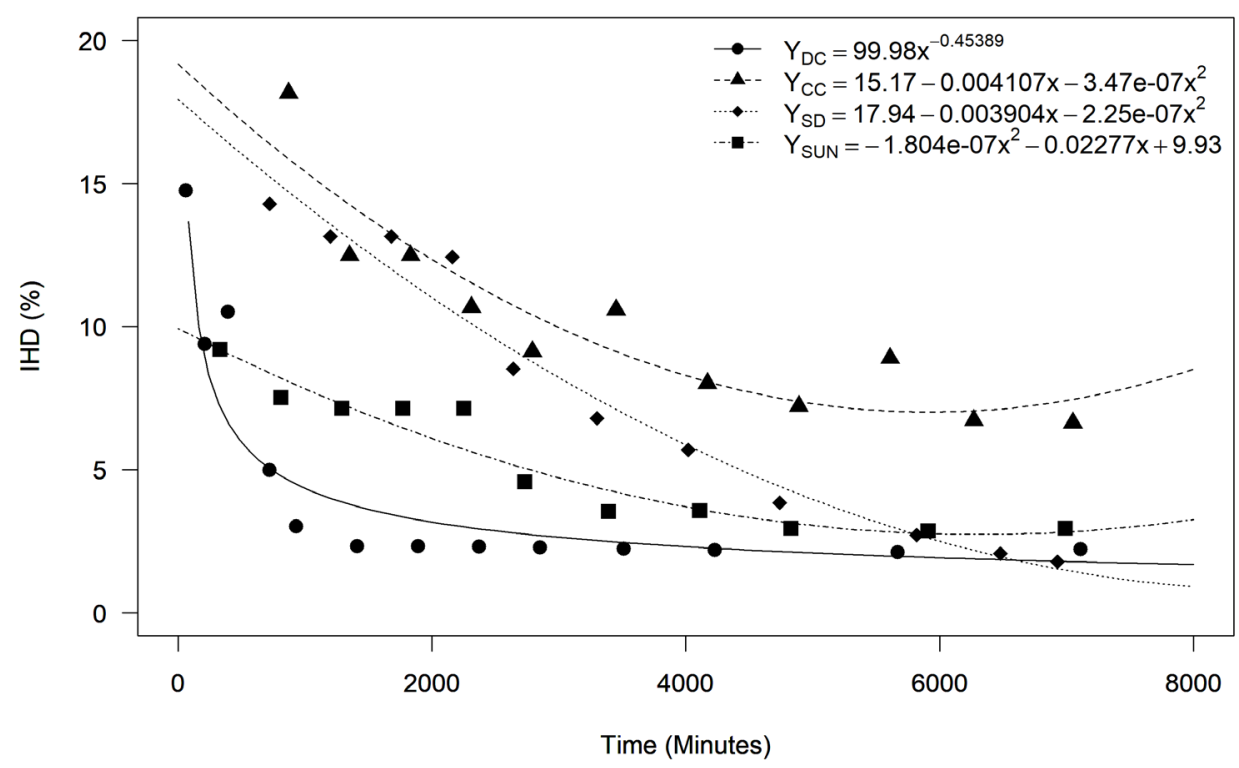

(B)

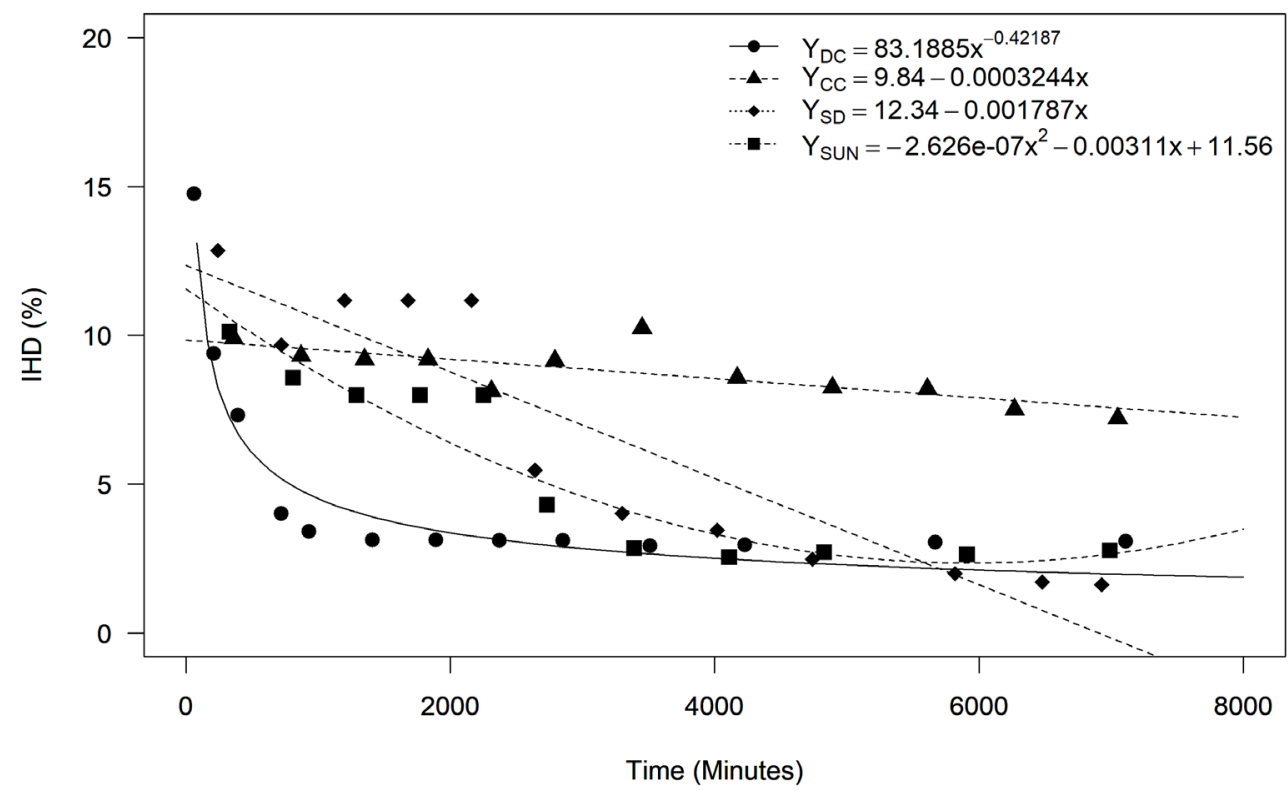

Figure 4 - Index of heterogeneity drying (IHD) of pomegranate peel subjected to 4 drying methods (full sun (SUN), drying chamber at $60 \pm 2{ }^{\circ} \mathrm{C}(\mathrm{DC})$, cold chamber at $10 \pm 2{ }^{\circ} \mathrm{C}$ and $60 \pm 5 \% \mathrm{RH}(\mathrm{CC})$ and solar dryer adapted from Cornejo et al. (1991) (SD)) with (A) and without (B) the application of 1\% ascorbic acid (Londrina-PR, 2019). 
Despite a noted time difference of approximately $4500 \mathrm{~min}, \mathrm{SUN}$ and SD treatments presented promising results to the small producer, as both allowed for a fast and uniform drying process. This could reduce the deterioration of pomegranate peels from moisture, and favor their shelf life by not compromising their nutritional properties, in addition to eliminating the need for a high financial investment (SILVA, 2015; SANTOS, 2010).
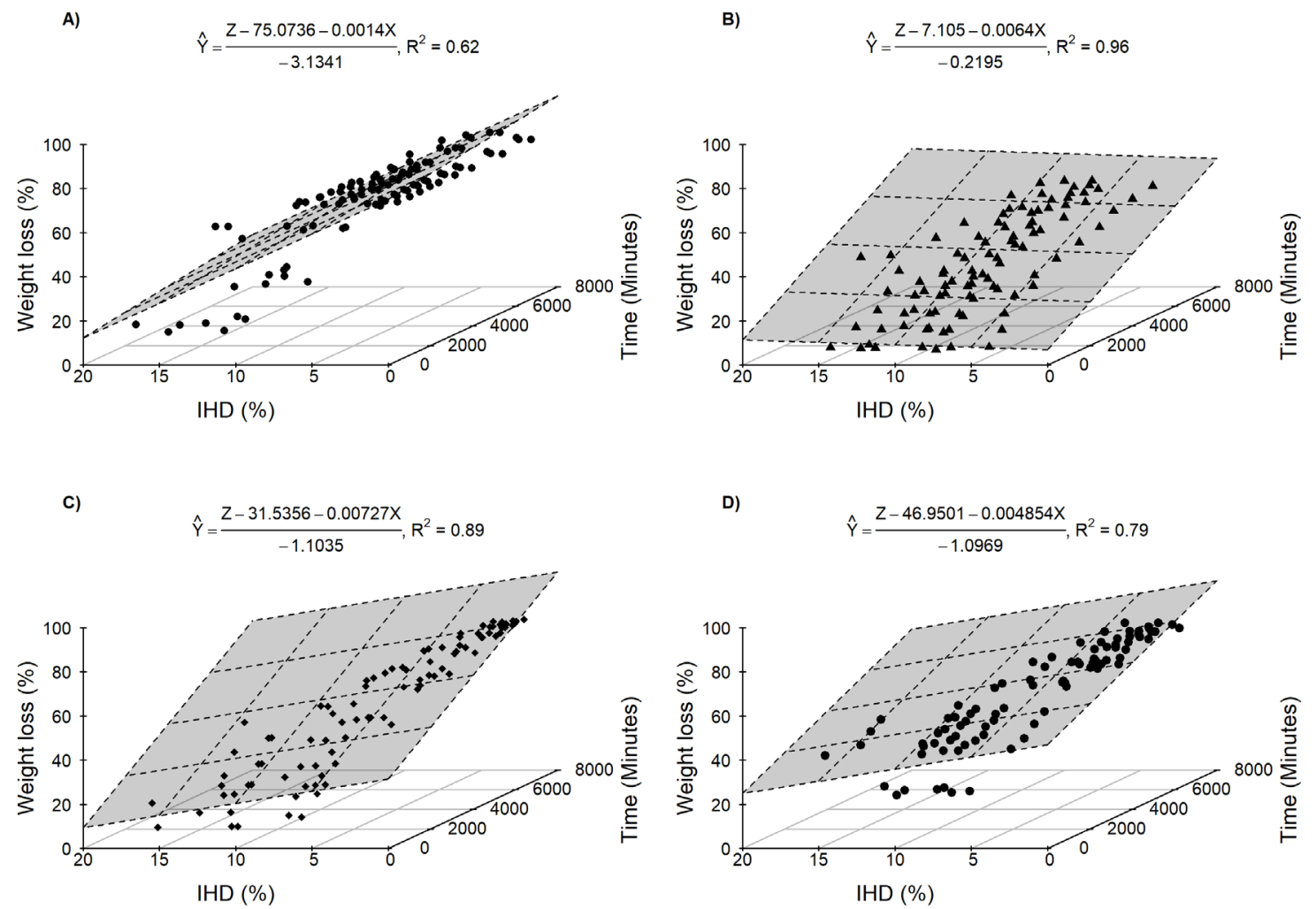

E)

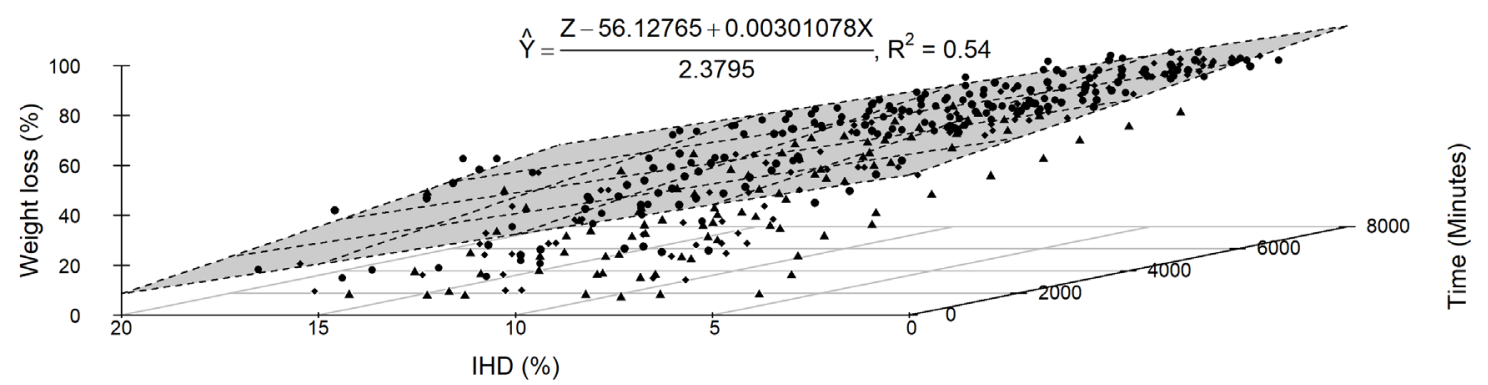

Figure 5 - Graph showing multiple linear regression models between the index of heterogeneity drying (\%), mass loss (\%) and time (min) variables for the following treatments: Drying chamber at $60 \pm 2{ }^{\circ} \mathrm{C}(\mathrm{A})$; cold chamber at 10 $\pm 2{ }^{\circ} \mathrm{C}$ and $60 \pm 5 \% \mathrm{RH}(\mathrm{B})$; Solar dryer (C) and full sun (D). Model with all values (E) (Londrina-PR, 2019). 
The internal luminosity of the peel (LIC) showed a significant response to the type of drying treatment, with CC displaying the best response with a lighter tone; similar observations were recorded for the external luminosity of the peel (LEC) (Table 2). Drying through cooling produced a decrease in the metabolism of fruit peels, reducing their oxidative effects and, consequently, mitigating the darkening of their surface (OLIVEIRA et al., 2008).
Horuz and Maskan (2015) reported similar observations when determining color alteration in pomegranate peels subjected to high temperatures and prolonged drying times. It was also observed that the internal and external luminosity of the peel was higher when ascorbic acid was not applied.

Table 2 - Internal luminosity of the peel (LIC); external luminosity of the peel (LEC); internal peel Chroma (CIC); external peel Chroma (CPB); Hue internal (HI) and external (HE) angles of pomegranate peels subjected to different drying methods (Sec.) and application of 1\% ascorbic acid (AA)(Londrina-PR, 2019).

\begin{tabular}{|c|c|c|c|c|c|c|c|}
\hline \multirow{2}{*}{ Peel } & \multirow{2}{*}{ Color } & \multirow{2}{*}{ AA } & & \multicolumn{4}{|c|}{ Drying methods } \\
\hline & & & & DC & $\mathrm{CC}$ & SD & SUN \\
\hline \multirow{3}{*}{ Internal } & $\mathrm{L}$ & $\begin{array}{c}\text { With } \\
\text { Without }\end{array}$ & $\begin{array}{c}43.00 \pm 5.92^{*} \\
45.60 \pm 6.57 \\
\end{array}$ & $43.25 \mathrm{~B} \pm 3.58$ & $53.41 \mathrm{~A} \pm 3.21$ & $40.70 \mathrm{~B} \pm 3.23$ & $39.76 \mathrm{~B} \pm 2.68$ \\
\hline & $\mathrm{C}^{(\mathrm{t})}$ & $\begin{array}{c}\text { With } \\
\text { Without }\end{array}$ & $\begin{array}{l}32.40 \pm 5.35^{*} \\
37.60 \pm 12.91 \\
\end{array}$ & $33.53 \mathrm{~B} \pm 2.85$ & $40.16 \mathrm{~A} \pm 3.08$ & $31.02 \mathrm{~B} \pm 2.80$ & $35.38 \mathrm{AB} \pm 19.3$ \\
\hline & $\mathrm{H}$ & $\begin{array}{c}\text { With } \\
\text { Without }\end{array}$ & $\begin{array}{c}85.19 \pm 3.60^{*} \\
87.75 \pm 1.00\end{array}$ & - & - & - & - \\
\hline \multirow{4}{*}{ External } & $\mathrm{L}$ & $\begin{array}{c}\text { With } \\
\text { Without }\end{array}$ & $\begin{array}{c}43.61 \pm 3.48^{*} \\
45.93 \pm 4.27 \\
\end{array}$ & $41.67 \mathrm{~B} \pm 1.51$ & $49.03 \mathrm{~A} \pm 1.57$ & $44.76 \mathrm{~B} \pm 5.13$ & $43.66 \mathrm{~B} \pm 2.67$ \\
\hline & $\mathrm{C}$ & With & - & $29.63 \mathrm{Ba} \pm 1.07$ & $34.69 \mathrm{Aa} \pm 1.68$ & $30.51 \mathrm{Bb} \pm 1.93$ & $31.66 \mathrm{Aba} \pm 3.01$ \\
\hline & & Without & - & $31.99 \mathrm{BCa} \pm 2.39$ & $37.00 \mathrm{Aa} \pm 0.56$ & $34.74 \mathrm{ABa} \pm 0.76$ & $30.10 \mathrm{Ca} \pm 3.35$ \\
\hline & $\mathrm{H}$ & $\begin{array}{c}\text { With } \\
\text { Without }\end{array}$ & $\begin{array}{c}65.44 \pm 5.77^{*} \\
60.26 \pm 4.93 \\
\end{array}$ & - & - & - & - \\
\hline \multicolumn{2}{|c|}{ Variable } & \multicolumn{2}{|c|}{$p$-valor Factor A } & \multicolumn{2}{|c|}{$p$-valor Factor B } & \multicolumn{2}{|c|}{$p$-valor A x B } \\
\hline \multirow{4}{*}{ Internal } & $\mathrm{L}$ & \multicolumn{2}{|c|}{0.009} & \multicolumn{2}{|c|}{$<0.001$} & \multicolumn{2}{|c|}{0.664} \\
\hline & $\mathrm{C}$ & \multicolumn{2}{|c|}{0.028} & \multicolumn{2}{|c|}{0.048} & \multicolumn{2}{|c|}{0.285} \\
\hline & $\mathrm{H}$ & \multicolumn{2}{|c|}{0.278} & \multicolumn{2}{|c|}{0.003} & \multicolumn{2}{|c|}{0.156} \\
\hline & $\mathrm{L}$ & & 0.002 & \multicolumn{2}{|c|}{0.017} & \multicolumn{2}{|c|}{0.058} \\
\hline \multirow[t]{2}{*}{ External } & $\mathrm{C}$ & & 0.003 & \multicolumn{2}{|c|}{0.013} & \multicolumn{2}{|c|}{0.043} \\
\hline & $\mathrm{H}$ & & 0.161 & \multicolumn{2}{|c|}{0.008} & \multicolumn{2}{|c|}{0.185} \\
\hline
\end{tabular}

Means followed by the same lowercase letter in the row and uppercase in the column do not differ by Tukey's test $(\mathrm{p}<0.05)$.

(t) Data transformed by Box-Cox (1964).

* significant at $5 \%$ by $\mathrm{F}$ test.

\pm indicates sample standard deviation.

Regarding the Hue angle, a significant effect of the application of ascorbic acid was observed in the internal (HI) and external (HE) part of the peel, which did not differ between drying methods (Table 2). The internal peel produced a more yellowish shade of color with the application of AA, while the external peel presented an inverse effect in the absence of AA, producing a darker color ranging from red/purple to opaque brown (MASKAN et al., 2002). This is because ascorbic acid can act as a pro-oxidant agent by forming dark pigments throughout its degradation or by reducing quinone, a compound responsible for forming colored polymers only when used in high concentrations (UNDERHILL and CRITCHLEY, 1992).

\section{Analysis of total phenolic compounds and flavonoids}

The content of total phenolic compounds and flavonoids presented an interactive effect between the factors. Thus, the application of ascorbic acid in the drying chamber at $60 \pm 2^{\circ} \mathrm{C}$ resulted in a marked reduction in both variables (Table 3 ). This can be explained by the 
addition of water from the application of ascorbic acid (AA) which, together with high temperature, can cause a severe denaturation of the compounds present in the pomegranate peel, in an effect similar to the technique of moist heat (RIGUEIRA et al., 2016). Comparisons within the levels of ascorbic acid application showed that the drying chamber treatment at $60 \pm 2^{\circ} \mathrm{C}$ presented a higher content of total phenolic compounds and flavonoids in the absence of AA, while the SD treatment displayed a reverse pattern, with higher values recorded when ascorbic acid was applied (Table 3). According to Brito (2000), a slower drying process favors the destruction of phenolic compounds, while heat treatment has a greater effect on the polyphenol contents in food products, and exhibits a positive relationship with increases in temperature (QUE et al., 2008), as observed with treatment in the cold chamber.

Table 3 - Total phenolic compounds (TCFT) and flavonoids (TFLA) of pomegranate peel subjected to different drying methods (Sec - Full sun (SUN), drying chamber at $60 \pm 2{ }^{\circ} \mathrm{C}(\mathrm{DC})$, cold chamber at $10 \pm 2{ }^{\circ} \mathrm{C}$ and $60 \pm 5 \% \mathrm{RH}(\mathrm{CC})$ and solar dryer (SD)) with (CAA) and without (SAA) the application of 1\% ascorbic acid (Londrina-PR, 2019).

\begin{tabular}{|c|c|c|c|c|}
\hline & \multicolumn{2}{|c|}{$\begin{array}{c}\text { TCFT } \\
\text {---mg GAE } 100 \mathrm{mg}^{-1}---\end{array}$} & \multicolumn{2}{|c|}{$\begin{array}{c}\text { TFLA } \\
\text {---mg QE } 100 \mathrm{mg}^{-1}---\end{array}$} \\
\hline & CAA & SAA & CAA & SAA \\
\hline $\mathrm{DC}$ & $297.8 \pm 38.1 \mathrm{Cb}$ & $982.7 \pm 89.8 \mathrm{Aa}$ & $38.3 \pm 5.3 \mathrm{Cb}$ & $128.2 \pm 11.1 \mathrm{Aa}$ \\
\hline $\mathrm{CC}$ & $716.9 \pm 265.7 \mathrm{Ba}$ & $680.2 \pm 156.7 \mathrm{Ba}$ & $91.5 \pm 34.1 \mathrm{Ba}$ & $92.6 \pm 17.6 \mathrm{Ba}$ \\
\hline $\mathrm{SD}$ & $1123.71 \pm 118.5 \mathrm{Aa}$ & $842.8 \pm 92.0 \mathrm{ABb}$ & $151.1 \pm 10.0 \mathrm{Aa}$ & $117.7 \pm 6.7 \mathrm{ABb}$ \\
\hline SUN & $878.56 \pm 148.4 \mathrm{ABa}$ & $860.0 \pm 142.3 \mathrm{ABa}$ & $115.4 \pm 18.6 \mathrm{Ba}$ & $120.1 \pm 16.1 \mathrm{ABa}$ \\
\hline Sec. (A) & \multicolumn{2}{|c|}{$0.0020261 *$} & \multicolumn{2}{|c|}{$0.0005021 *$} \\
\hline $\mathrm{AA}(\mathrm{B})$ & \multicolumn{2}{|c|}{0.1108492} & \multicolumn{2}{|c|}{$0.0155334 *$} \\
\hline$A \times B$ & \multicolumn{2}{|c|}{$<0.0001369 *$} & \multicolumn{2}{|c|}{$<0.0001 *$} \\
\hline
\end{tabular}

Means followed by the same lowercase letter in the row and uppercase in the column do not differ by Tukey's test $(\mathrm{p}<0.05) .{ }^{*}$ significant at $5 \%$.

The synthesis of phenolic compounds is derived from the partial oxidation of sugars and organic acids in cell respiration (i.e., during glycolysis and in the cycle of tricarboxylic acids). It is therefore possible that a fraction of the acids and sugars were used as a source of carbon skeletons for the synthesis of phenolic compounds, since higher storage temperatures resulted in a higher respiratory rate (SOETHE et al., 2016).

\section{Conclusions}

Dehydration in a drying chamber at $60 \pm 2^{\circ} \mathrm{C}$ required a shorter time to reach a stable mass and should not be used with ascorbic acid, as the latter resulted in the reduction of total phenolic compounds and flavonoids.

The solar dryer, despite being a slower method than the drying chamber at $60 \pm 2^{\circ} \mathrm{C}$, minimized the loss of total phenolic compounds and flavonoids in the presence of ascorbic acid, which could be of interest to the consumer.

The cold chamber drying process proved to be an inadequate method for drying the pomegranate peel.

The application of ascorbic acid may inhibit darkening of the peel. However, attention should be paid to the concentration used, since it can also produce undesirable effects.
Data from total phenolic compounds and flavonoids also indicated that treatment in the solar dryer with ascorbic acid produced higher levels of these compounds than when compared to treatment without AA application. There is evidence that although drying in SD is slower and causes the degradation of these compounds, these effects can be minimized when associated with AA. This method therefore suggests a low-cost option for the small rural producer that allows maintaining the antioxidant potential of the pomegranate peel.

\section{Acknowledgements}

Thanks go to the Coordination for the Improvement of Higher Education Personnel (CAPES), for the granting of scholarship to the first author, and to the State University of Londrina for its premises and research facilities.

\section{References}

AOAC - Association of Official Analytical Chemists. Official methods of analysis. $16^{\text {th }} \mathrm{ed}$. Washington, 1997.

BOX, G.E.P.; COX, D.R. An analysis of transformations. Journal of the Royal Statistical Society, London, v.26, p.211-252, 1964. 
BRITO, E.S. Estudo de mudanças estruturais e químicas produzidas durante a fermentação, secagem e torração de amêndoas de cacau (Theobroma cacao L.) e propostas de tratamento para o melhoramento de sabor. 2000. Tese (Doutorado em Tecnologia de Alimentos) - Universidade Estadual de Campinas, Campinas, 2000.

CAZARIN, C.B.B; SILVA, J.K. da; COLOMEU, T.C.; LIMA ZOLLNER, R. de; MARÓSTICA JUNIOR, M.R. Capacidade antioxidante e composição química da casca de maracujá (Passiflora edulis). Ciência Rural, Santa Maria, v.44, n.9, 2014.

CORNEJO, F.E.P; PARK, K.J.; NOGUEIRA, R.I.; MAIA, M.L.L.; PONTES, S.M.; SILVA, C.D. Manual para construção de um secador de frutas a nível do produtor rural. Guaratiba: EMBRAPA-CTAA, 1991.

COSTA, A.C. Estudo da conservação do pêssego (Prunus persica L.) minimamente processado. 2010. Tese (Doutorado em Ciência e Tecnologia Agroindustrial) - Universidade Federal de Pelotas, Pelotas, 2010.

CRISTOFORI, V.; CARUSO, D.; LATINI, G.; DELL'AGLI, M.; CAMMILLI, C.; RUGINI, E.; BIGNAMI C.; MULEO, R. Fruit quality of Italian pomegranate (Punica granatum L.) autochthonous varieties. European Food Research and Technology, Berlin, v.232, p.397-403, 2011.

HOLLAND, D; BAR-YA'AKOV, I. The pomegranate: new interest in an ancient fruit. Chronica Horticulturae, Leuven, v.48, p.12-15, 2008.

HORUZ, E.; MASKAN, M. Hot air and microwave drying of pomegranate (Punica granatum L.) arils. Journal of Food Science and Technology, Ottawa, v.52, n.1, p.285293, 2015.

JALAL, H.; PAL, M.A.; AHMAD, S.R.; RATHER, M.; ANDRABI, M.; HAMDANI, S. Physico-chemical and functional properties of pomegranate peel and seed powder. The Pharma Innovation Journal, New Delhi, v.7, n. 4, p.1127-1131, 2018.

MACHADO, A.V.; OLIVEIRA, E.L.; SANTOS, E.S.; OLIVEIRA, J.A.; FREITAS, L.M. Estudo da influência da espessura no tempo de secagem do pedúnculo de caju em secadores solar de radiação direta e indireta. Revista Verde, Mossoró, v.7, n.1, p.256-263, 2012.
MASHAVHATHAKHA，K.L.; SOUNDY, P.; NGEZIMANA, W.; MUDAU, F.N. Evaluation of physico-chemical properties of pomegranate (Punica granatum L.) cultivar 'Wonderful' on three locations of South Africa. Tropical Agriculture, Trinidad, v. 91, n.3, p.157-164, 2014.

MASKAN, A.; KAYA, S.; MASKAN, M. Effect of concentration and drying processes on color change of grape juice and leather (pestil). Journal of Food Engineering, Amsterdam, v.54, p.75-80, 2002.

MAYUONI KIRSHINBAUM, L.; PORAT, R. The flavor of pomegranate fruit: a review. Journal of the Science of Food and Agriculture, New York, v.94, n.1, p.21-27, 2014.

MCGUIRE, R.G. Reporting of objective color measurements. Horticultural Science, Prague, v.27, p.1254-1255, 1992.

OLIVEIRA, T.M.; SOARES, N.D.F.F.; PAULA, C.D.; VIANA, G.A. Uso de embalagem ativa na inibição do escurecimento enzimático de maçãs. Semina: Ciências Agrárias, v. 29, n. 1, p. 117-128, 2008. DOI: http://dx.doi. org/10.5433/1679-0359.20

OMAIAA - Observatório dos Mercados Agrícolas e das Importações Agro-alimentares. A comercialização da romã em Portugal. 2011. Disponível em: http://www. observatorioagricola.pt/item.asp?id item $=118$. Acesso em: 17 mar. 2013.

PAPADAKIS, S.E.; ABDUL-MALEK, S.; KAMDEM, R.E.; YAM, K.L. A versatile and inexpensive technique for measuring color of foods. Food Technology, Chicago, v.54, p.48-51, 2000.

QU, W.; BREKSA, A.P.; PAN, Z.; MA, H. Quantitative determination of major polyphenol constituents in pomegranate products. Food Chemistry, London, v.132, n.3, p.1585-1591, 2012.

QUE, F.; MAO, L.; FANG, X.; WU, T. Comparison of hot air drying and freeze drying on the physicochemical properties and antioxidant activities of pumpkin (Cucurbita moschata Duch.) flours. International Journal of Food Science \& Technology, Oxford, v.43, n.7, p.1195-1201, 2008.

R Core Team. R: a language and environment for statistical computing. Austria: R Foundation for Statistical Computing, Vienna, 2019. Disponível em: https://www.Rproject.org/. (5) 
RIGUEIRA, G.D.J.; BANDEIRA, A.V.M.; CHAGAS, C.G.O.; MILAGRES, R.C.R.M. Atividade antioxidante e teor de fenólicos em couve-manteiga (Brassica oleracea L. var. acephala) submetida a diferentes sistemas de cultivo e métodos de preparo. Semina: Ciências Biológicas e da Saúde, Londrina, v.37, n.2, p.3-12, 2016.

ROCHA, A.M.C.N.; MORAIS, A.M.M.B. Shelf life of minimally processed apple (cv. Jonagored) determined by color changes. Food Control, New York, v.14, n.1, p.13-20, 2003.

SAAD, H.; CHARRIER-EL BOUHTOURY, F.; PIZZI, A.; RODE, K.; CHARRIER, B.; AYED, N. Characterization of pomegranate peels tannin extractives. Industrial Crops and Products, Amsterdam, v.40, p.239-246, 2012.

SALGADO, J.M.; FERREIRA, T.R.B.; BIAZOTTO, F.O.; DIAS, C.T.S. Increased antioxidant content in juice enriched with dried extract of pomegranate (Punica granatum) peel. Plant Foods for Human Nutrition, Dordrecht, v.67, n.1, p.39-43, 2012.

SANTOS, F.S. dos; LEITE, D.D.F.; FIGUEIRÊDO, R.M.F. de; QUEIROZ, A.J.M. Modelagem matemática da cinética de secagem da romã. Revista Espacios, Caracas, v.38, n.52, p.27, 2017.

SANTOS, K.O.; NETO, B.A.M; OLIVEIRA, S.; RAMOS, M.E.C.; AZEVEDO, L.C. Obtenção de farinha com o resíduo da acerola (Maplpighia glabra L.). In: CONGRESSO DE PESQUISA E INOVAÇÃO DA REDE NORTE NORDESTE DE EDUCAÇÃO TECNOLÓGICA, 5., 2010. Maceió. Anais [...]. Maceió: IFAL, 2010.

SARKHOSH, A.; ZAMANI, Z.; FATAHI, R.; RANJBAR, $H$. Evaluation of genetic diversity among Iranian softseed pomegranate accessions by fruit characteristics and RAPD markers. Scientia Horticulturae, New York, v.121, p.313-319, 2009.

SEERAM, N.P., SCHULMAN, R.N.; HEBER, D. Pomegranates: ancient roots to modern medicine. Boca Raton: CRC Press Taylor and Francis Group, 2006.

SILVA, D.F.P.; LINS, L.C.R. de; MATIAS, R.G.P.; ALVES, R.R.; SALOMÃO, L.C.C. Ácido ascórbico na redução do escurecimento do pericarpo e na qualidade póscolheita de lichia. Revista Engenharia na AgriculturaReveng, Viçosa, MG, v.22, n.6, p.503-508, 2014.

SILVA, P.B. Secagem de resíduos de frutas em secador roto-aerado. Dissertação (Mestrado em Engenharia Química) - Universidade Federal de Uberlândia, Uberlândia, 2015.
SINGLETON, V.L.; ROSSI, J.A. Colorimetry of total phenolics with phosphomolybdic-phosphotungstic acid reagents. American Journal of Enology and Viticulture, Davis, v.16, n.3, p.144-158, 1965.

SOETHE, C.; STEFFENS, C.A.; AMARANTE, C.V.T.; MARTIN, M.S.; BORTOLINI, A.J. Qualidade, compostos fenólicos e atividade antioxidante de amoras pretas' Tupy' e 'Guarani' armazenadas a diferentes temperaturas. Pesquisa Agropecuária Brasileira, Brasília, DF, v.51, n.8, p.950-957, 2016.

SUZUKI, E.T. Avaliação fenológica, análise econômica e estudo da cadeia produtiva da romã (Punica granatum). Tese (Doutorado) - Faculdade de Ciências Agronômicas, Universidade Estadual Paulista, Botucatu, 2016.

TEHRANIFAR, A.; ZAREI, M.; NEMATI, Z.; ESFANDIYARI, B.; VAZIFESHENAS, M.R. Investigation of physico-chemical properties and antioxidant activity of twenty Iranian pomegranate (Punica granatum L.) cultivars. Scientia Horticulturae, New York, v.126, n.2, p.180-185, 2010.

TONTUL, I; TOPUZ, A. Effects of different drying methods on the physicochemical properties of pomegranate leather (pestil). LWT - Food Science and Technology, Amsterdam, v.1, n.80, p.294-303, 2017.

UNDERHILL, S.J.R.; CRITCHLEY, C. The physiology and anatomy of lychee (Litchi chinensis Sonn.) pericarp during fruit development. Journal of Horticultural Science, Ashford, v.67, n.3, p.437-444, 1992.

UNECE - United Nations Economic Commission for Europe. Standard for pomegranate. Genebra, 2013. p. 1-5. (Codex Stan 310-2013)

WATANABE, H.S.; OLIVEIRA, S.L. Comercialização de frutas exóticas. Revista Brasileira de Fruticultura, Jaboticabal, v.36, n.1, p.23-38, 2014

WOISKY, RG; SALATINO, A. Analysis of propolis: some parameters on procedure for chemical quality control. Journal Apicultural Research, Cardiff, v.37, n.2, p.99$105,1998$. 